\title{
Role of biotechnology in developing the bioenergy sector in Poland
}

\author{
MAURYCY DAROCH ${ }^{1 *}$, Michal Mos ${ }^{2 *}$ \\ ${ }^{1}$ Biosciences Building, School of Biological Sciences, University of Liverpool, Liverpool, United Kingdom \\ ${ }^{2}$ Bioenergy and Environmental Change, IBERS, Plas Gogerddan, University of Aberystwyth, Aberystwyth, United Kingdom \\ * Corresponding authors: imm@aber.ac.uk, m.daroch@liverpool.ac.uk \\ (both authors contributed equally to the publication)
}

\begin{abstract}
The Polish economy is facing a green revolution with the implementation of European Union (EU) directive $2009 / 28 / \mathrm{EC}$ on the promotion of the use of energy from renewable sources. Poland could benefit substantially from this shift as it has one of the highest hectarage per capita in the EU and therefore has land resources that could be used for growing plant-based renewable energy sources. However, the development of domestic technologies and know-how is essential if Poland is to take full advantage of the opportunities. Biotechnology should play a pivotal role in the development of technologies which would lead to a bio-based economy for Poland. However, this would require the synergistic action of many sectors: research and development, legislation, and essentially capital investment. This review aims to summarise current biotechnological approaches to bioenergy and to demonstrate how they relate to scientific and economic potential in Poland.
\end{abstract}

Key words: biotechnology, bioenergy, biofuel

\section{Introduction}

\section{Economic, political and ecological foreword}

In 2008, oil prices reached their all-time record and, although the cost of crude oil has fallen substantially due to the global economic crisis, fossil fuels are still becoming increasingly expensive. Production of oil is already at its peak even according to the most optimistic scenario, and it seems therefore that we have already approached the limit of energy output using the existing technology (Sorrell, 2009). Other fossil fuels such as coal and gas are also being depleted much more quickly than it was anticipated (Rutledge 2008), with the remaining deposits becoming increasingly uneconomical and/or dangerous to extract (Probierz and Borowka, 2009).

To put things into a political context, the European Union (EU) is dependent on imports of fossil fuels from Russia and Middle East. This is not an ideal situation as it means the energy security of over 500 million people and the first World economy (taking EU GDP as unity) (IMF, 2010) is reliant upon non-EU countries, a disruption of this supply would cause severe economic and social problems. History shows that supply disruption is possible as every few years disputes have arisen between Russia and its Eastern European trade partners namely Ukraine (Lowe and Polityuk 2009) and Belarus (Osborn, 2010) or between the United States and OPEC in 1970s (Songstad et al., 2009) leading to the interruption of the energy supply.

Our reliance on fossil fuels and the more intensive searches for new deposits also have ecological consequences. The intensive search for new sources increases the possibility of ecological catastrophes similar to the one in the Gulf of Mexico (Zeller Jr., 2010) and dangerous mine explosions e.g. Upper Big Branch, Virginia, US (Urbina, 2010) or Wujek-Śląsk, Ruda Śląska, Poland (PAP, 2009). More importantly fossil fuels are the biggest contributor to climate change resulting from greenhouse gas emissions (Vitousek, 1994; Le Quere et al., 2009). To start to address some of these problems, the EU aims for the average share of the market for renewable energy (bioenergy, wind, solar, tidal, etc.) to increase to $20 \%$ by 2020 for all European countries. As well as aiming for a decrease in total energy consumption, the EU is promoting an increase in the use of biofuels, and other renewable fuels for transport - and has set a target of a 10\% share of the market by 2020 (European Commission, 2009). 


\section{Biomass, biofuel and bioenergy}

In order to reach the 2020 targets, EU countries are constantly working towards increasing the proportion of the market occupied by renewable energies. In 2007, renewables accounted for $16.4 \%$ of the European (EU-25) energy supply, compared to $12.6 \%$ in 2004 , with nearly half of these renewable sources coming from biomass (Berent-Kowalska, 2009). In 2006, over three quarters of the $13 \%$ World share of renewable energy was from biomass (Bauen, 2009).

The use of biomass for energy generation was widespread until the industrial revolution; the excessive consumption caused deforestation and the subsequent lack of wood that resulted in a shift towards coal and other fossil fuels. Currently, the concept of using biomass as a main source of energy returns in a broader context. Biomass sources include agricultural and forest residues, biodegradable communal waste and dedicated energy crops such as Miscanthus, Poplar (Populus sp.) and Willow (Salix sp.). Biofuel feedstocks include the first generation energy crops such as, rapeseed, sunflower, corn (Jaradat, 2010). Second generation crops are: short rotation coppice trees, Miscanthus and Jatropha (Jaradat, 2010). The third generation biofuel feedstocks are based on micro and macro algae (Goh and Lee, 2010). Although very promising, second and third generation energy crops still possess a number of limitations that hinder their broader usage. Various third generation species possess a number of disadvantages that currently limit their applicability. Willow yields high biomass content but is susceptible to more diseases and pest than other biomass crops (Roylea and Ostryb, 1995; Choluj et al., 2010). It also requires large water inputs and its wood has high moisture content, which is undesirable (Matyka, personal communication). Miscanthus, on the other hand, does not seem to have those drawbacks, however the planting material cost is currently high (reviewed in Atkinson, 2009) and some genotypes suffer from overwintering problems in their first year in some regions of Northern Europe (Clifton-Brown and Lewandowski, 2000). In all biomass species additional improvement of yield and/or pest resistance or robustness against environmental conditions would improve the overall economics of the process.

\section{Biotechnology and bioenergy}

Biotechnology is a very diverse and dynamic field at the interface of science and technology and offers enor- mous potential for the development of bioenergy. Many aspects of plant and industrial biotechnologies can solve problems that have hindered the progress of bioenergy in recent decades. Generally, plant biotechnology (green) focuses on feedstock, whereas industrial (white) biotechnology focuses on the conversion of this feedstock to value added products; however there are exceptions to this rule.

Plant biotechnology offers methods that already serve bioenergy needs and there is an array of techniques currently applied to food crops, which can be implemented to energy crops e.g. herbicide resistance of Roundup $^{\circledR}$ ready corn. These techniques can be divided into three main fields: tissue culture technology; quantitative trait locus and marker assisted plant breeding; and genetically modified (GM) crops. Industrial biotechnology offers advances in biochemical engineering (bioreactor design), strain improvement and directed evolution of enzymes for biomass conversion. These aspects can significantly increase the economics of biofuel production and make them cost-competitive with gasoline and diesel.

These are areas where Poland already has relevant expertise e.g. tissue culture technology is applied at many research centres e.g. IHAR (Institute of Plant Breeding and Acclimatization), agricultural universities of Cracow and Warsaw and private enterprises. Marker technologies and GM trials are performed at IHAR. White biotechnology is mainly applied in technical universities of Łódź, Wrocław and Warsaw. We believe that Polish science and technology should take advantage of this expertise and contribute to a new bioenergy-based economy.

\section{Renewable energy resources of Poland}

According to the Central Statistical Office (Wiśniewski, 2007), in 2006, the total energy output from renewableenergies in Poland was estimated to be $210,513 \mathrm{TJ}$ of energy, of which total direct biomass combustion contributed to $91.4 \%$. Advanced biomass processing like biofuels (first generation biodiesel and bioethanol) and biogas contributed to $3.3 \%$ and $1.2 \%$ respectively. The remaining $4.1 \%$ was generated by wind, solar and hydro installations. Taking into consideration the electricity generation in 2006, almost a half (48\%) of renewable electricity was generated in hydro power plants, $6 \%$ was contributed by wind turbines, whilst the remaining $46 \%$ was generated by biomass (biomass combustion, co-fi- 
ring and biogas production). The same study indicates that biomass conversion has the greatest potential of all renewable energy sources for Poland, with the dedicated lignocellulose energy crops being the largest contributor of this potential. Another study analyses the land suitability for various bioenergy crops (Fischer et al., 2010). According to the data, $33 \%$ of available agricultural land in Poland is considered 'very suitable' for herbaceous crops like Miscanthus, whereas $14 \%$ of this land is 'very suitable' for woody crops such as Willow and Poplar. A more detailed study of current Polish biomass market is available elsewhere (Burczy et al., 2010) and is beyond the scope of this review.

\section{Improvement of bioenergy feedstock}

Currently, all the available biomass feedstocks have specific issues regarding downstream processing and conversion. Even simple and well-understood biomass conversion technologies such as combustion encounter issues relating to differences in the inorganic composition of biomass feedstocks which may lead to corrosion, fouling, slagging, and reduction of the lifespan of boiler systems (Demirbas, 2005). Bioethanol production from cellulose suffers from lignin interference (Demain, 2009; Kuhad et al., 2010). Some biomass crops are easily attacked by pests and pathogens. Biomass feedstock can be improved with a variety of methods from the repertoire of green biotechnology e.g. the tissue culture technologies, micropropagation and germplasm genetic differentiation. Micropropagation of sterile clones of the leading biomass crop Miscanthus $x$ giganteus, for example, is a cost-effective method of preparing biomass planting material and offers substantial savings when compared to its vegetative propagation (Lewandowski, 1998). This approach has the added advantage of providing disease-free copies of the best available clone.

Germplasm genetic differentiation can be achieved via two routes: production of double haploid lines and the use of somaclonal variation for plant improvement (Bednareket al.,2007). Production of haploid and double haploid lines through the processes of androgenesis and gynogenesis has long been applied to many traditional crop species such as wheat and corn (Thorpe, 2007). It shortens the time to obtain homozygous lines for breeding by elimination of repetitive back-crossing. Haploidisation has already been performed for Poplar (Hoa and Raja, 1985) and advances are currently being made to create haploid and double haploid lines of Miscanthus and Willow (Glowacka, personal communication). Other problems may also need to be addressed, for example some potentially useful crops are generated by crossing two species of plant, however the resultant hybrids are frequently sterile, e.g. the triploids that result from a Miscanthus $x$ giganteus cross, which leads to high planting costs due to the need for vegetative or tissue culture propagation. Chromosome doubling through treatment with the antimitotic agent colchicine has been recently performed to create a fertile hexaploid from the infertile result of the Miscanthus $x$ giganteus cross. Chromosome doubling was successful, however the fertility results are not yet known (Chang et al., 2009). Exploration of the potential of somaclonal variants is yet to be applied to energy crops, however a few examples can be found for edible and ornamental plants and traits developed with this method include herbicide resistance and salt tolerance (Larkin and Scowcroft, 1981; Jain, 2001).

Another important field where plant biotechnology can contribute to bioenergy development, though is currently being neglected in the EU, is the area of transgenic crops. Since its introduction in 1997, there have been numerous debates about the pros and cons of this technology; however, they are outside the scope of this publication. GM technology can offer significant improvements of yield through herbicide or pesticide resistance and improved protection against insects and/or viruses. These individual traits can be obtained by expressing one or up to a few protein products (Hailes, 2000). GM technology can also be implemented to improve non-agricultural traits. Methods to facilitate the downstream processing of the crop into value added products are currently being developed. Two fields have been already explored. The antisense RNA technology can be applied to silence genes responsible for negative traits like high lignin content, which can be altered to decrease its interference in the saccharification process (Lee et al., 1997; Hu et al., 1999). Another method to facilitate saccharification is expressing a sugar hydrolysing enzyme in the crop, rather than adding them to the process (Borkhardt et al., 2010). This approach can provide substantial savings as cellulases and hemicellulases are currently the main contributors to the high cost of lignocellulose biofuels. In summary, GM technology can offer improvements in both agricultural and downstream processing traits but more work needs to be 
done in this field, especially on species that cannot be propagated generatively.

A technology at the interface between germplasm differentiation and GM is protoplast fusion. This technique enables the DNA of two plant species to be combined to create a hybrid with a novel set of characteristics (Liu et al., 2005). The overall use of this technology has seriously declined since the introduction of GM technology but it still has significant potential. Another alternative to GM technology, which can improve the quality of energy crops, is the use of quantitative trait locus (QTL) identification and marker-assisted plant breeding. This allows significant time and cost savings when compared with traditional phenotype-based breeding methods (Bernardo, 2008; Heffner et al., 2009).

The improvement of bioenergy feedstock via biotechnological methods can be performed in many ways; these include accelerated plant breeding, changes in the content and regulation of genes through tissue culture methods and the introduction of foreign genes to obtain specific traits. Propagation of planting material is another area where plant biotechnology plays a role through micropropagation and attempts to restore the fertility of Miscanthus $x$ giganteus.

Plant biotechnology is one of the fields where Polish science and technology is strong and can compete at the highest level, particularly in the area of tissue culture (Glowacka et al., 2009; Plazek and Dubert, 2009; Wojciechowicz and Kikowska, 2009). However, other aspects of green biotechnology in the biofuel field require improvement if Poland is to play a significant role in the bio-based economy of $21^{\text {st }}$ century.

\section{Biomass conversion technologies}

Lignocellulose is a key building block of plant tissues and is the largest source of renewable energy. It is a complex biopolymer composed of three major components: cellulose, lignin, hemicellulose, along with very small amounts of other components such as pectins, proteins, ash and/or lipids (Dashtban et al., 2009). An array of parameters should be taken into consideration when choosing optimal conversion technology; some feedstocks are more suitable for combustion (Monti et al., 2008), others for biochemical conversion (Diena et al., 2006). The calorific value of biomass that characterises biomass feedstock for combustion mainly depends on moisture; lignin and ash contents. Biomass with higher lignin content will burn longer, delivering more energy. Biomass for biochemical conversion should be characterised by high carbohydrate content - preferably easily hydrolysable, amorphous cellulose or hemicellulose and sucrose. Such feedstock should have limited content of lignin to decrease its negative effect on cellulose hydrolysis (Sun and Cheng, 2002). With this in mind, one can now select the appropriate crop-method combination for energy production from lignocellulose biomass from the range of those currently available. These technologies can be broadly divided into thermochemical and biochemical, a summary of which can be found in Figure 1, which presents a concept of advanced biorefinery that converts various feedstocks into electricity, heat and value added products with a combination of technologies that maximize output and minimize cost.

\section{Thermochemical convertion}

The most efficient way to convert biomass to energy (electricity, heat or process steam) developed to date is based on thermochemical conversion. Although not quite a biotechnology, the advanced thermochemical conversion of biomass is perceived to be an essential part of future biorefineries (Fig. 1) and thus should be considered as a part of this review. Large scale combustion and co-combustion of biomass with coal in heat and power plants is still based on the old technology of a domestic fire and boiler (Goyal et al., 2008). At present, lignocellulosic biomass only represents 5-15\% share of the total thermal input in Polish power plants, although new facilities are being developed, which may increase this percentage up to $40 \%$ (Savolainen, 2003) mainly through the introduction of dedicated biomass power plants (Ciepiela, 2010). Currently, co-combustion of biomass in coal-fired power plants is the single largest growing sector of renewables in many EU countries and an important contributor of national renewable energy targets in the United States and China (Al-Mansour and Zuwala, 2010). The sector is growing steadily each year and plays a very important role in the Polish bioenergy sector (Ericsson, 2007). Currently, it seems that biomass co-firing with coal is the only possibility for Poland if it is to reach the $7.5 \%$ renewables target in 2011 and subsequent years (Berggren et al., 2008).

Most popular advanced techniques for biomass conversion in Poland are coal gasification and pyrolysis. 


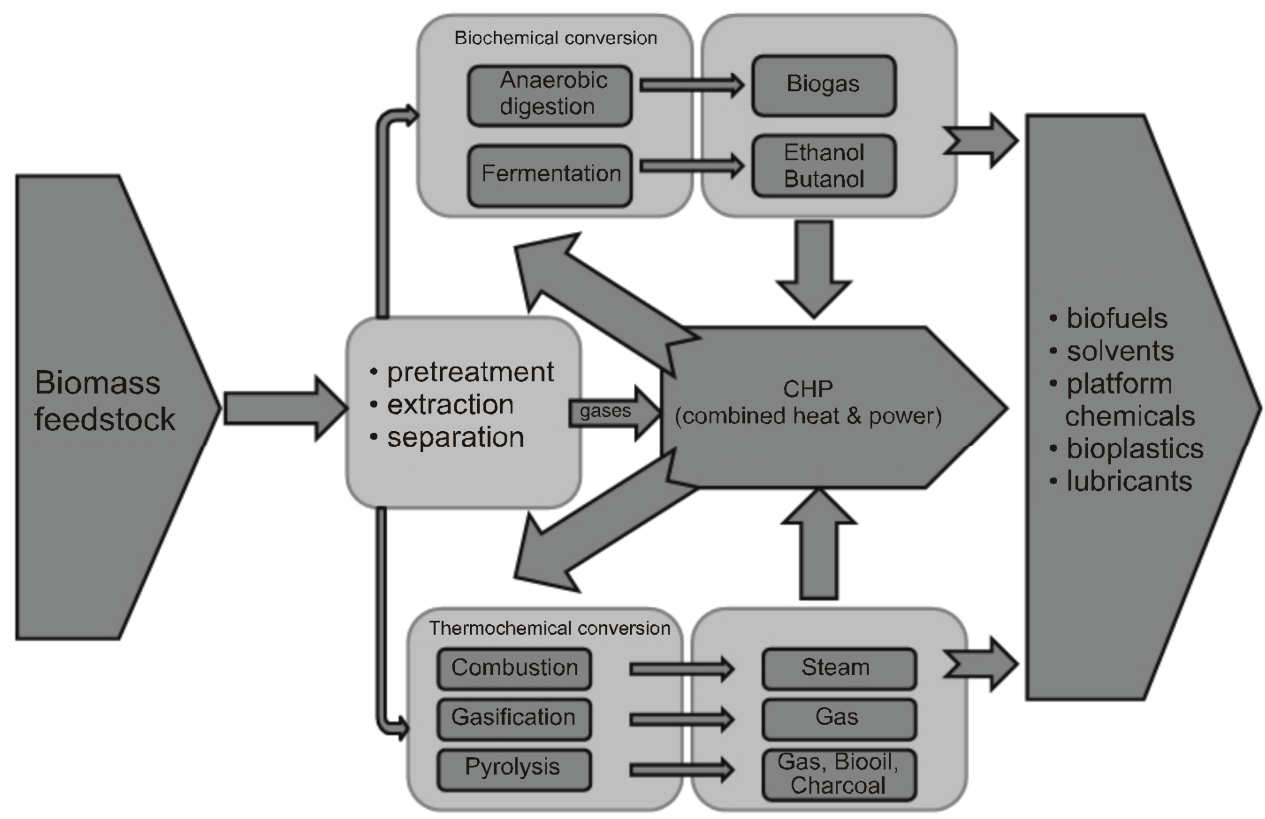

Fig. 1. A modern concept of an integrated biorefinery.

Regional feedstock is supplied to the refinery, it is composed of biodegradable waste, forestry residues and dedicated biomass crops. After separation into different groups, an appropriate method of processing is selected for each group. Easily fermentable materials undergo biochemical conversion, whilst the more resistant materials are subjected to thermochemical conversions. As a result of this process, an array of value added products such as biofuels or platform chemicals are obtained and rest of the feedstock is transformed into heat and power by a combined heat and power unit.

These techniques have been studied since 1955 at the Institute for Chemical Processing of $\mathrm{Coal}(\mathrm{IChPW})$ in the south of Poland, (Dziunikowski, 1955). Gasification is a process of coal conversion at temperatures exceeding $800^{\circ} \mathrm{C}$ with a controlled supply of air or water vapour. The gasification process is performed on various biomass and/or waste feedstocks that are transformed into combustible gas or syngas. The two main advantages of gasification are (i) the conversion of a low density bulk product into high density versatile fuel/platform chemicalsand(ii) the possibility of hydrogen production, which is the most valuable bioenergy product (Lin et al., 2002).

The most promising and technologically advanced form of thermal conversion is pyrolysis. This is a process that converts biomass at a temperature of around 500$600^{\circ} \mathrm{C}$ to the liquid form. The reaction proceeds without, or with a very limited, supply of oxygen in less than two seconds. Pyrolysis vapours are rapidly cooled and condensed to liquid products. The main pyrolysis products are liquid bio oil, commonly referred to as a bio-crude (75\%), along with charcoal (12\%) and gases (13\%). Bio oil can be used as a hydrocarbon platform for the synthesis of other compounds. Charcoal can be deposited underground to sequester carbon i.e. temporarily remove it from the carbon cycle of environment (Bridgwater et al., 1999; Hodgson et al., 2010).

Although very promising, advanced thermochemical biomass conversion on a large scale, or even on demonstration scale, is quite expensive. Currently, these technologies in terms of cost-effectiveness cannot compete with fossil fuels with similar characteristics. The reason for this large cost difference between pyrolysis and fossil fuel technologies is that the fossil fuel technologies are already widespread and have been fully optimised whereas advanced pyrolysis and gasification are still in their infancy. It has been predicted that costs can be decreased by up to $75 \%$ when these technologies reach maturity and more plants have been constructed (Bridgwater et al., 2002; Oasmaa et al., 2010). Although currently cost-prohibitive, if Polish bioenergy sector is to be in a good position in the future, it is essential that even small scale installations are introduced and that Polish universities and science institutes initiate collaboration with top level specialists in the field.

\section{Biochemical conversion}

The biochemical conversion of starch feedstocks, such as maize, to biofuels and other energy sources held 
much promise. However, due to climate change and other demands, agricultural land is becoming increasingly sparse and is needed for food production, which results in insufficient land for the growth of plant biomass for fuels. The process is also economically unviable (Festel, 2008; Gomez et al., 2008). Consequently, current development is focussed on the commercialization of technologies that either use lignocellulose waste or employ dedicated biomass crops that can be grown on marginal lands not suitable for food production. As a result of these findings, current efforts have shifted from starch conversion (first generation biofuels) to lignocellulose conversion (second generation biofuels). Unlike starch, lignocellulose is a structure of incredible resistance to degradation often described as biomass recalcitrance. The main structural component of lignocellulose is cellulose - a highly crystalline polymer composed of D-glucose, just like starch. The key difference between the two structures is the glycosidic bond which is oriented in a $\beta(1 \rightarrow 4)$ fashion opposite to starch that is mainly composed of $\alpha(1 \rightarrow 4)$ linked D-glucose with occasional $\alpha(1 \rightarrow 6)$ branching. Lignin is another main component of lignocellulose. It is linked to sugar components of lignocellulose forming a physical seal that protects cellulose and hemicellulose from microbial attack and oxidative stress. Lignin also has a major function to play as structural support for the plant (Leonowicz et al., 1999; Sanchez, 2009). Lignin is the most recalcitrant polymer to decompose and is degraded by fungi via oxidative reactions sometimes described as enzymatic combustion. Degradation of all plant cell wall components requires synergistic actions of many classes of enzymes that are specific for individual components of the biopolymer. Among the best degraders of lignocellulose are fungi, mainly basidiomycetes and anaerobic bacteria (Beguin and Lemaire, 1996; Perez et al., 2002; Dashtban et al., 2009). These enzymatic machineries can be exploited in the process of biochemical conversion of biomass. The whole process can be divided into two parts: decomposition of feedstock and synthesis of products. The enzymatic biochemical processes used in biomass decomposition are delignification and saccharification, which are performed by peroxidases/laccases and glycoside hydrolases, respectively.

Enzymatic saccharification of lignocellulose is the conversion of feedstock to fermentable sugars. It is believed to be the most promising eco-friendly route for obtaining carbon source for fermenting microorganisms. However, it is currently regarded as a major cost contributor of the saccharification process due to the costs of the enzymes (Lin and Tanaka, 2006). Current lignocellulose fermentation technology employs an array of physical and physiochemical methods of biomass pre-treatment that are used before biomass saccharification can be started. Pre-treatment procedures liberate cellulose chains from lignin and increase the contact area between the enzyme and its substrate. Currently employed technologies include: mechanical pre-treatment (grinding, milling, chipping), steam explosion, ammonia fibre explosion, $\mathrm{CO}_{2}$ explosion, ozonolysis, acid and alkaline hydrolysis, oxidative delignification, organosolv processes and biological delignification (Sun and Cheng, 2002). Enzymatic delignification of biomass is not currently implemented in lignocellulose biofuel production practice and lignin is usually burnt as a waste product (Kim and Dale, 2005). However, white biotechnology could offer much more to this area as lignin, instead of being a waste product, could be a useful source of phenolic compounds in integrated processes (Kumar et al., 2009). There is a lot of interest in the usage of enzymes and other process improvements that would reduce the cost of saccharification, a step that is needed if the cost of biofuels is to compete effectively with that of fossil fuels (Percival Zhang et al., 2006; Gomez et al., 2008). To make the costs of enzymatic delignification and saccharification competitive, it is essential that there are advances in solid state substrate enzymology, process engineering and enzyme technology at both the molecular and process levels.

After the decomposition of feedstock is completed, there are a number of methods of converting these materials into value added products like biofuels. Two biochemical routes are available such as liquid biofuel or gaseous biofuel conversion. The former employs the processes of ethanol and acetone-butanol-ethanol (ABE) fermentation (Pfromm et al., 2010), the latter focuses on anaerobic digestion to form biogas (Gunaseelan, 1997). Although ethanol fermentation with yeast is a well-known process that uses Saccharomyces cerevisiae to convert glucose to ethanol, significant advances are needed to allow fermentation of both pentoses and hexoses. These improvements have been obtained through molecular strain engineering and have allowed the utilization of both cellulose and hemicellulose components of feed- 
stock (Hahn-Hagerdal et al., 2007). However, despite these advances, there is still a need for improvements in strain robustness against the high ethanol content and the presence of furfural and phenolics that result from the lignin decomposition (Palmqvist and Hahn-Hagerdal, 2000; Kuhad et al., 2010). These problems could be solved using classical strain mutagenesis or molecular biology techniques (Lin and Tanaka, 2006). Biobutanol production faces similar challenges as the main butanol-producing strain, Clostridium acetobutyricum, is highly affected by the high butanol concentration generated in the bioreactor. These problems can be tackled either through strain engineering or by bioreactor construction which leads to reduced butanol concentration (Papoutsakis, 2008). Anaerobic digestion of biomass to create biogas has been the most popular technology in Poland so far. Consequently, current research in the field focuses on the optimization of biomass input to the digester (reactor) and process conditions (Kacprzak et al., 2010). However, strain improvement is difficult due to very heterogeneous nature of both substrates and biocatalysts.

In the white biotechnology sector, Poland already has substantial experience in biodiesel production (Kociolek-Balawejder and Pinkowska, 2008; Antczak et al., 2009) and ethanol fermentation for human consumption aswellas first generation bioethanol (Białas et al., 2010). There are also a number of institutes dealing with chemical and process engineering (Kacprzak et al., 2010; Piela et al., 2010). There is considerable high level expertise in classical enzymology (Pyc et al., 2005; Rogalski et al., 2006; Jamroz et al., 2007) and although the molecular side of biofuel production (enzyme engineering, strain improvement) has substantial potential, it has yet to be fully exploited.

\section{Discussion}

Poland's potential for biofuel production is currently associated with land potential (Kondili and Kaldellis, 2007 ) and resembles the $16^{\text {th }}$ century concept of the 'granary of Europe'. We believe that Poland could and should offer more towards the area of bioenergy and biofuels. The opportunity exists for this country to become a world leader in the sector and a significant supplier of renewable energy in the EU.

Summarising the current achievements in the biotechnology-bioenergy sector (in Poland), it seems that the fields of expertise cover biodiesel (Antczak et al.,
2009), tissue culture technology (Glowacka et al., 2009) and chemical engineering (Szewczyk and Bukowski, 2008). Many authors suggest that the use of biodiesel made from rapeseed should no longer be pursued. Rapeseed was found as a non-eco-friendly alternative due to the negative energy and $\mathrm{CO}_{2}$ balance produced by rapeseed biodiesel, which contributes to global warming (Faaij, 2006). The growth of rapeseed also requires high quality soils and large fertilizer inputs that should be rather used for food production. However, one should note that technologies developed for rapeseed biodiesel can be successfully used for waste conversion into biodiesel (Shimada et al., 2002).

The authors submit that the following issues must be addressed if Poland is to take the lead in the bioenergy sector. Certain legislative changes and Government incentives are needed to:

- attract private investment to promote dedicated energy crops, e.g. the establishment of regional biomass centres and energy crops schemes;

- provide investment for the start-up companies in the bioenergy sector;

- establish large-scale projects to promote knowledge transfer between white biotechnology, green biotechnology, farming and engineering. These projects should act in conjunction with the private sector and venture capital, to allow rapid commercialisation of new technologies;

- establish a network of interested parties.

However, most of these initiatives have to be Government lead, while the organisation of large, multi-disciplinary, consortia could be initiated by either the private sector or the scientists themselves, who could then apply for large EU research grants under FP7 (www. cordis.europa.eu) or the Innovative Economy Programme (www.poig.gov.pl). The importance of working in closer collaboration with other European states and countries as the US, Australia, Brazil or China should not be overlooked as there are numerous grant opportunities for international collaboration such as, inter alia COST (www. cost.esf.org), EUREKA (www.eurekanetwork. org), MarieCurie IAPP, Marie-Curie IOF (www.cordis.europa.eu). Another avenue worth remembering is establishing contacts with numerous Polish expatriates who may be willing to work with scientists in their home country.

In conclusion, Poland's land mass combined with its expertise in biotechnology offers huge potential for the 
development of the Polish bioenergy sector. In addition to the obvious economic benefits such development would activate farming, reduce unemployment and increase energy security and sustainability. Polish biotechnology can play a significant role in this transformation if appropriate changes in its legislation and attitude are introduced. The transformation of the energy sector will happen eventually, the question is whether Poland can grab the opportunity to become the 'energy granary of Europe' or whether it will take a minimalistic approach and become just a feedstock supplier.

\section{References}

Al-Mansour F., J. Zuwala (2010) An evaluation of biomass cofiring in Europe. Biomass Bioenergy 34(5): 620-629.

Antczak M.S., Kubiak A. et al. (2009). Enzymatic biodiesel synthesis - Key factors affecting efficiency of the process. Renewab. Ener. 34(5): 1185-1194.

Atkinson C.J. (2009) Establishing perennial grass energy crops in the UK: A review of current propagation options for Miscanthus. Biomass Bioenergy 33(5): 752-759.

Bauen A. (2009). IEA Bioenergy Annual Report 2009.

Bednarek P.T., Orlowska R. et al. (2007) Quantification of the tissue-culture induced variation in barley (Hordeum vulgare L.). BMC Plant Biol. 7.

Berent-Kowalska G. (2009) Energia ze Źródeł odnawialnych w $2008 r$. Informacje i opracowania statystyczne, GUS.

Berggren M., Ljunggren E. et al. (2008) Biomass co-firing potentials for electricity generation in Poland-Matching supply and co-firing opportunities. Biomass Bioenergy 32(9): 865-879.

Bernardo R. (2008). Molecular markers and selection for complex traits in plants: Learning from the last 20 years. Crop Sci. 48(5): 1649-1664.

Białas W., Szymanowska D. et al. (2010) Fuel ethanol production from granular corn starch using Saccharomyces cerevisiae in a long term repeated SSF process with full stillage recycling. Biores. Technol. 101: 3126-3131.

Borkhardt B., Harholt J. et al. (2010) Autohydrolysis of plant xylans by apoplastic expression of thermophilic bacterial endo-xylanases. Plant Biotech. J. 8(3): 363-374.

Bridgwater A.V., Meier D. et al. (1999) An overview of fast pyrolysis of biomass. Org. Geochem. 30(12): 1479-1493.

Bridgwater A.V., Toft A.J. et al. (2002) A techno-economic comparison of power production by biomass fast pyrolysis with gasification and combustion. Renewab. Sustain. Ener. Rev. 6(3): 181-246.

Burczy H., Mirowski T. et al. (2010) Study on Biomass Trade in Poland. IEN.

Chang Y.Y., Hyoung S.K. et al. (2009) Chromosome doubling of the bioenergy crop, Miscanthus $x$ giganteus. GCB Bioener. 1: 404-412.
Choluj D., Podlaski S. et al. (2010) Parametry fizjologiczne determinujące plon biomasy roślin energetycznych. Nowoczesne technologie pozyskania i energetycznego wykorzystania biomasy. Instytut Energetyki, Warszawa.

Ciepiela D. (2010) Dalkia w Eodzi i Poznaniu zbuduje kotły wyłącznie na biomasę. Retrieved 18 May 2010, from http://energetyka.wnp.pl/dalkia-w-lodzi-i-poznaniu-zbudujekotly-wylacznie-na-biomase,110156_1_0_0.html.

Clifton-Brown J.C., Lewandowski I. (2000) Overwintering problems of newly established Miscanthus plantations can be overcome by identifying genotypes with improved rhizome cold tolerance. New Phytol. 148(2): 287-294.

Dashtban M., Schraft H. et al. (2009) Fungal bioconversion of lignocellulosic residues; Opportunities \& perspectives. Int. J. Biol. Sci. 5(6): 578-595.

Demain A.L. (2009) Biosolutions to the energy problem. J. Ind. Microbiol. Biotechnol. 36(3): 319-332.

Demirbas A. (2005) Potential applications of renewable energy sources, biomass combustion problems in boiler power systems and combustion related environmental issues. Progr. Energy Combus. Sci. 31(2): 171-192.

Diena B.S., Hans-Joachim J.G. et al. (2006) Chemical composition and response to dilute-acid pretreatment and enzymatic saccharification of alfalfa, reed canarygrass, and switchgrass. Biomass Bioener. 30(10): 880-891.

Dziunikowski K. (1955) Underground gasification of coal in Poland. Wiad. Górn. 6: 102-105.

Ericsson K. (2007) Co-firing - A strategy for bioenergy in Poland? Energy 32(10): 1838-1847.

European Commission (2009) EU Action against climate change. Leading global action to 2020 and beyond. European Commission, Luxembourg.

Faaij A.P.C. (2006) Bio-energy in Europe: changing technology choices. Ener. Policy 34: 322-342.

Festel G.W. (2008) Biofuels - Economic aspects. Chem. Eng. Tech. 31(5): 715-720.

Fischer G., Prieler S. et al. (2010) Biofuel production potentials in Europe: Sustainable use of cultivated land and pastures. Part I: Land productivity potentials. Biomass Bioener. 34(2): 159-172.

Glowacka K., Jezowski S. et al. (2009). Polyploidization of Miscanthus sinensis and Miscanthus $x$ giganteus by plant colchicine treatment. Industr. Crops Prod. 30(3): 444-446.

Goh C.S., Lee K.T. (2010) $A$ visionary and conceptual macroalgae-based third-generation bioethanol (TGB) biorefinery in Sabah, Malaysia as an underlay for renewable and sustainable development. Renew. Sustain. Ener. Rev. 14(2): 842-848.

Gomez L.D., Steele-King C.G. et al. (2008) Sustainable liquid biofuels from biomass: the writing's on the walls. New Phytol. 178(3): 473-485.

Goyal H.B., Seal D. et al. (2008) Bio-fuels from thermochemical conversion of renewable resources: A review. Renew. Sustain. Ener. Rev. 12(2): 504-517.

Gunaseelan N.V. (1997). Anaerobic digestion of biomass for methane production: A review. Biomass Bioener. 13(1-2). 
Hahn-Hagerdal B., Karhumaa K. et al. (2007) Towards industrial pentose-fermenting yeast strains. Appl. Microbiol. Biotechnol. 74(5): 937-953.

Hailes R.S. (2000) Genetically modified plants - the debate continues. Trends Ecol. Evol. 15(1): 14-18.

Heffner E.L., Sorrells M.E. et al. (2009) Genomic selection for crop improvement. Crop Sci. 49(1): 1-12.

Hoa R., Raja Y.(1985) Haploid plant production through anther culture in poplars. Forest Ecol. Manag. 13(3-4): 133-142.

Hodgson E.M., Fahmi R. et al. (2010) Miscanthus as a feedstock for fast-pyrolysis: Does agronomic treatment affect quality? Bioresour. Technol. 101(15): 6185-6191.

$\mathrm{Hu}$ W.J., Harding S.A. et al. (1999) Repression of lignin biosynthesis promotes cellulose accumulation and growth in transgenic trees. Nature Biotechnol. 17(8): 808-812.

IMF (2010) World economic outlook database, April 2010. International Monetary Fund.

Jain S.M. (2001) Tissue culture-derived variation in crop improvement. Euphytica 118(2): 153-166.

Jamroz T., Sencio B. et al. (2007) Efficiency of laccase biosynthesis in various types of fermenters. J. Biotechnol. 131(2): S161-S161.

Jaradat A.A. (2010) Genetic resources of energy crops: Biological systems to combat climate change. Austral. J. Crop Sci. 4(5): 309-323.

Kacprzak A., Krzystek L. et al. (2010) Co-digestion of agricultural and industrial wastes. Chem. Paper. 64(2): 127-131.

Kim S., Dale B.E. (2005) Life cycle assessment of various cropping systems utilized for producing biofuels: Bioethanol and biodiesel. Biomass Bioener. 29(6): 426-439.

Kociolek-Balawejder E., Pinkowska H. (2008) Ion exchange resins in manufacturing and purifying biodiesel oil as well as purifying and utilization of glicerol. Przemysl Chem. 87(10): 1012-1018.

Kondili E.M., Kaldellis J.K. (2007) Biofuel implementation in East Europe: Current status and future prospects. Renew. Sustain. Ener. Rev. 11: 2137-2151.

Kuhad R.C., Gupta R. et al. (2010) Bioethanol production from Lantana camara (red sage): Pretreatment, saccharification and fermentation. Bioresour. Technol. 101(21): 8348-8354.

Kumar S., Singh S.P. et al. (2009) Recent Advances in Production of Bioethanol from Lignocellulosic Biomass. Chem. Engin. Technol. 32(4): 517-526.

Larkin P.J., Scowcroft W.R. (1981) Somaclonal variation a novel source of variability from cell-cultures for plant improvement. Theor. Appl. Gen. 60(4): 197-214.

Le Quere C., Raupach M.R. et al. (2009) Trends in the sources and sinks of carbon dioxide. Nature Geosci. 2(12): 831-836.

Lee D., Meyer K. et al. (1997) Antisense suppression of 4-coumarate: coenzyme A ligase activity in Arabidopsis leads to altered lignin subunit composition. Plant Cell 11: 1985-98.

Leonowicz A., Matuszewska A. et al. (1999) Biodegradation of lignin by white rot fungi. Fungal Gen. Biol. 27(2-3): 175-185.
Lewandowski I. (1998) Propagation method as an important factor in the growth and development of Miscanthus $x$ giganteus. Ind. Crops Prod. 8(3): 229-245.

Lin S., Harada M. et al. (2002) Hydrogen production from coal by separating carbon dioxide during gasification. Fuel 81(16): 2079-2085.

Lin Y., Tanaka S. (2006) Ethanol fermentation from biomass resources: current state and prospects. Appl. Microbiol. Biotech. 69(6): 627-642.

Liu J.H., Xu X.Y. et al. (2005) Intergeneric somatic hybridization and its application to crop genetic improvement. Plant Cell Tiss. Organ Cult. 82(1): 19-44.

Lowe C., Polityuk P. (2009) Russia cuts off gas to Ukraine. Retrieved 1 January 2009, from http://www.reuters.com/ article/idUSTRE4BN32B20090101.

Monti A., Di Virgilio N. et al. (2008) Mineral composition and ash content of six major energy crops. Biomass Bioener. 32(3): 216-223.

Oasmaa A., Solantausta Y. et al. (2010) Fast pyrolysis bio-oils from wood and agricultural residues. Energy Fuels 24(2): 1380-1388.

Osborn A. (2010) 'Gas war' breaks out between Russia and Belarus. Retrieved 22 June 2010.

Palmqvist E., Hahn-Hagerdal B. (2000) Fermentation of lignocellulosic hydrolysates II: inhibition and detoxification. Biores. Technol. 74: 25-33.

PAP (2009) Tragedia w kopalni. Dwunastu górników nie żyje. Retrieved 2009-09-18, from http://katowice.gazeta.pl/ katowice/1,35063,7054230,Tragedia_w_kopalni__Dwun astu_gornikow_nie_zyje.html.

Papoutsakis E.T. (2008) Engineering solventogenic clostridia. Curr. Opin. Biotech. 19(5): 420-429.

Percival Zhang Y.H., Himmel M.E. et al. (2006) Outlook for cellulase improvement: Screening and selection strategies. Biotech. Adv. 24(5): 452-481.

Pfromm P.H., Amanor-Boadu V. et al. (2010) Bio-butanol vs. bio-ethanol: A technical and economic assessment for corn and switchgrass fermented by yeast or Clostridium acetobutylicum. Biomass Bioener. 34(4).

Piela P., Michalowski T. et al. (2010) Can a fermentation gas mainly produced by rumen isotrichidae ciliates be a potential source of biohydrogen and a fuel for a chemical fuel cell? J. Microbiol. Biotech. 20(7): 1092-1100.

Plazek A., Dubert F. (2009) Optimization of medium for callus induction and plant regeneration of Miscanthus $x$ giganteus. Acta Biol. Cracovien. Ser. Bot. 51: 56-56.

Probierz K., Borowka B. (2009) Prognosis about sufficiency of hard coal resources in upper silesian coal basin and analisis about reasons of decrease of the resources in some mines. Gospod. Sur. Mineral. (Miner. Res. Manag.) 25(3): 7-20.

Pyc R., Sojka-Ledakowicz J. et al. (2005) Biosynthesis of multienzymatic preparation from Aspergillus niger IBT-90 useful in textile fabric treatment. J. Biotech. 118: S127-S127.

Rogalski J., Szczodrak J. et al. (2006) Manganese peroxidase production in submerged cultures by free and immobili- 
zed mycelia of Nematoloma frowardii. Biores. Techn. 97(3): 469-476.

Roylea D.J., Ostryb M.E. (1995). Disease and pest control in the bioenergy crops poplar and willow. Biomass Bioener. 9(1-5): 69-79.

Rutledge D. (2008) Hubbert's Peak, The coal question, and climate change. 2008. 33rd International Conference on Infrared, Millimeter and Terahertz Waves, 1-2: 83-83.

Sanchez C. (2009) Lignocellulosic residues: Biodegradation and bioconversion by fungi. Biotech. Adv. 27(2): 185-194.

Savolainen K. (2003) Co-firing of biomass in coal-fired utility boilers. Appl. Ener. 74(3-4): 369-381.

Shimada Y., Watanabe Y. et al. (2002) Enzymatic alcoholysis for biodiesel fuel production and application of the reaction to oil processing. J. Mol. Catal. B: Enzym. 17: 133142.

Songstad D.D., Lakshmanan P. et al. (2009) Historical perspective of biofuels: learning from the past to rediscover the future. In Vitro Cell. Dev. Biol. Plant 45(3): 189-192.

Sorrell S.A.S. Jr. (2009) Global oil depletion: an assessment of the evidence for near-term physical constraints on global oil supply.
Sun Y., Cheng J. (2002) Hydrolysis of lignocellulosic materials for ethanol production: a review. Biores. Techn. 83(1): $1-11$.

Szewczyk K.W., Bukowski J. (2008) Modelling of a batch anaerobic digestion. Pol. J. Chem. Technol. 10(1): 45-48.

Thorpe T.A. (2007) History of plant tissue culture. Mol. Biotech. 37(2): 169-180.

Urbina I. (2010) No Survivors Found After West Virginia Mine Disaster. Retrieved April 9, 2010, from www.nytimes. com/2010/04/10/us/10westvirginia.html.

Vitousek P.M. (1994) Beyond global warming - ecology and global change. Ecology 75(7): 1861-1876.

Wiśniewski (2007). Możliwości wykorzystania odnawialnych źródeł energii w Polsce do roku 2020. Instytut Energetyki Odnawialnej, Warszawa.

Wojciechowicz M., Kikowska M. (2009) Induction of multinucleate microspores in anther culture of Salix viminalis L. Dendrobiology 61: 55-64.

Zeller Jr. T. (2010) Estimates suggest spill is biggest in U.S. history. Retrieved 27 May 2010, from www.nytimes.com/ 2010/05/28/us/28flow.html. 